\title{
INFLUENCE OF GENERATIONAL CHANGES ON THE DEVELOPMENT OF TEACHING METHODS IN THE FIELD OF TEACHING INFORMATION AND COMMUNICATION TECHNOLOGIES
}

\author{
Beata $\mathrm{HYSA}^{1 *}$, Iwona ZDONEK ${ }^{2}$ \\ ${ }^{1}$ Politechnika Śląska, Gliwice; beata.hysa@polsl.pl, ORCID: 0000-0003-1192-9395 \\ ${ }^{2}$ Politechnika Śląska, Gliwice; iwona.zdonek@polsl.pl, ORCID: 0000-0002-3377-0904 \\ * Correspondence author
}

Purpose: The purpose of this paper is to explore why and how generational changes and modern ICT have contributed to the development of didactic methods used by academic teachers in the field of teaching information and communication technologies (ICT).

Design/methodology/approach: In-depth interviews were conducted with academic teachers who have been working at a university for 10 to 20 years. They do classes for full-time and part-time students, teaching mainly science subjects.

Findings: This article clarifies why and how generational changes and modern ICT have contributed to the development of educational methods used by academic teachers. The article describes three generations of students: X, Y, Z, which are currently undertaking intramural and extramural studies. The report contains an analysis of the results of research concerning the work of contemporary academic teachers in terms of educational methods, teaching materials, methods of communication with students, evaluation, and control methods. The conclusions provided answers to the research questions.

Research limitations/implications: The article presents the results of qualitative research, which allowed us to initially determine the characteristics of the phenomenon of generational changes and its influence on the methods of teaching used. In the next stage of the research, the authors intend to conduct surveys among academic teachers and students to explore this topic from the point of view of quantitative analysis.

Originality/value: This study indicated that generational changes had transformed the teaching and working methods of academic teachers. However, this transformation does not mean the complete abandonment of previously used teaching methods, but their enrichment with new techniques related to ICT and social media.

Keywords: modern teaching methods, higher education, ICT technologies.

Category of the paper: research paper. 


\section{Introduction}

In the last decade, the rapid development of current information and communication technologies (ICT) has significantly changed the practice of many professions and occupations, and the job of an academic teacher is no exception. For a long time now, primary and secondary schools have been using multimedia projectors, interactive whiteboards, and e-learning platforms in their lessons. In higher education, this process is also present, although it started a bit later. Nowadays, the traditional manner of teaching is quickly becoming integrated with new technologies, and more and more universities have decided to educate students in the e-learning model ${ }^{1}$. The use of new forms and methods of teaching is somewhat forced by the generational change, because, among the students, there are people from Generations $\mathrm{Y}$ and $\mathrm{Z}$. Traditional forms of communication with students and academic teachers are more and more often accompanied by tools based on modern technologies and Internet communication. The authors of the article considered it essential to examine how modern ICT influences teaching methods and media and whether the generational change related to contemporary students forces academic teachers to use different teaching methods than those used in their educational process.

The article is organized as follows: The first chapter presents literature considerations concerning the generational diversity of contemporary students. The second chapter shows the methodology used in research. The third chapter contains an analysis of the results of a study concerning the work of present academic teachers in terms of educational methods and tools, as well as means of communication. The material for analysis was collected during in-depth interviews with academic teachers. The interviews were conducted among 15 persons during the academic year 2018/2019. Job seniority of teachers participating in the study was between 10 and 20 years. The article ended with conclusions presented in Chapter 4.

\footnotetext{
${ }^{1}$ E-learning is defined as "a method of conducting the didactic process in conditions where the lecturer and the students are not physically in the same place. Various media are used to transfer knowledge, including ICT", cf. Kisielnicki J. \& Nowacka B. (2013), Modele nauczania e-learningowego i ich ocena. Analiza porównawcza na przykładzie PJWSTK i Uczelni Łazarskiego in Postępy e-edukacji, L. Banachowski, Ed. Warsaw: PJWSTK Publishing House, 2013, pp. 41-52.
} 


\section{Generational diversity of contemporary students}

Assuming that a generation is a separable group of people who are connected by a similar time of birth and significant events at critical stages of development. It is possible to point out three generations ${ }^{2}$ of people who undertake studies at Polish universities (full-time and parttime). These are Generation X (born between 1965 and 1980), Generation Y (born between 1981 and 1994) and Generation Z (born after 1995). Each of these generations grew up and developed in different historical, economic and social circumstances, which translates into a different style of learning and interpretation of the surrounding world (Hysa, 2016).

Generation X. In Poland, Generation X represents mature people, i.e., today's forty- and fifty-year-olds, who grew up and entered adult life in the times of restructuring the economy. Inflation, intensification of unemployment, and instability of employment forced them to accept temporary agreements and accept jobs below their qualifications. The times when they had to start their careers made them enterprising people, but also increased the atmosphere of uncertainty and fear of losing their jobs. However, as mature people, they are most often the owners of large enterprises, as well as supervisors and teachers for generations $\mathrm{Y}$ and $\mathrm{Z}$. Those from Generation $\mathrm{X}$ are willing to learn and supplement their knowledge and skills. As a result, even though they were born in the analog era, they perfectly fit into the modern digital world and advanced technologies (Grenčíková; Vojtovič, 2017). In addition to e-learning courses, WebQuests, and online learning, they appreciate traditional methods of learning and acquiring information (books, classroom courses, lectures).

Generation Y. In both Polish (Kopertyńska, Kmiotek, 2014; Gadommska-Lila, 2015) and foreign literature (Luscombe et al., 2013; Lyons et al., 2015; The Deloitte Millennial Survey, 2017), much attention is paid to Generation Y (the so-called Millennials) born between 1981 and 1994. In Poland, this group is the first generation of Poles brought up and educated in a capitalist environment. They grew up in the era of universal computerization, the development of the Internet, and satellite television. The lack of political and social restrictions, the possibility of economic emigration, freedom of speech, and modern communication technologies were an actual reality for them. Generation $\mathrm{Y}$ is, therefore, a group of people who quickly reach information, create communities, like fast communication and have a great need to surround themselves with electronics (Stosik \& Leśniewska, 2015). What distinguishes them from their predecessors is a greater focus on themselves, their needs, and their benefits. Their principal values are ambition, creativity, innovation, and development. Their weaknesses include a lack of patience and self-discipline, as well as weaker decision-making abilities (Beckman et al., 2014). Therefore, the educational methods dedicated to them must go hand in

\footnotetext{
${ }^{2}$ It is worth noting that this is a conventional division of generations, which, in literature, is not clearly defined and differs from country to country. This division does not directly reflect the replacement of generations (i.e. every 20-25 years), but concerns people born at a similar time and shaped by similar events and experiences.
} 
hand with what they experience in everyday life. Informative content must be delivered as quickly as possible, in small portions, using new technologies, best suited to the preferences and expectations of particular individuals. As they have been using modern technology since childhood, the use of IT tools by academic teachers is becoming a natural and effective way to involve this generation in the educational process. Generation Y consists of people who have always texted, sent photos, and used new forms of communication (YouTube, Facebook, Twitter). They are accustomed to tiny portions of information and have limited time to concentrate. They will not engage in multi-module, in-depth, and extensive educational projects.

Generation $\mathbf{Z}$ consists of people born after 1995, for whom the virtual and real-world is the same reality. They cannot function without the Internet and electronic media, because, for them, these are part of the ordinary and everyday environment (Dolot, 2018). They look for diversity, escape from routine, willingly communicate with other cultures, want to go abroad to learn foreign languages and travel. More than independent work, they value teamwork. They can do many things at the same time, but it is difficult for them to focus on one activity. For Generation Z, the most important thing is what happens in the virtual world Snapchat, Instagram, and, of course, Facebook are the places where they spend most of their time (JWT Report, 2019). They transfer their contacts with their friends to the Internet level, limiting their meetings in the real world to a minimum. They often value the possibility of continuous functioning and communication via the Internet more than material goods, going to the cinema together with friends or sports activities. They prefer to use books with the help of e-book readers or audiobooks. They know how to find the information they need quickly, but they are not always able to select and use it in practice. They like to learn and gather knowledge online, via YouTube channels and free e-learning platforms. That is why such initiatives as, for example, Khan Academy, which focuses on mini-lectures in the form of educational films, are becoming popular. Thanks to early learning of the English language, verified by exams, they have no problems using English language programs or instructional materials. Generation $\mathrm{Z}$ is a big challenge for teachers because these individuals get boring quickly and need diversity and constant new stimuli. This generation learns best from multimedia materials and expects results immediately. The reason for this is the significant presence of games in their lives. Therefore, teaching methods that allow for the use of games in the educational process are becoming more and more popular. 


\section{Methods}

To examine the impact of generational change on the development of research methods. The research process has been organized in such a way as to answer the following questions:

1. Does generational change for modern students force academic teachers to use teaching methods other than those used in their educational process?

2. How does modern ICT affect teaching methods and media?

In response to such questions, in-depth interviews were conducted with 15 academic teachers between October and December 2018. All teachers participating in the survey have been working at a university for 10 to 20 years. They conduct classes for full-time and part-time students, teach mainly science subjects, such as computer science, information systems, statistics, operational research, IT tools in logistics, Internet technologies. The form of classes conducted by academic teachers includes lectures, exercises, laboratories, and projects. The questions that were asked in interviews with teachers concerned about various aspects related to the work of an academic teacher. Thus, they concerned multiple methods of conducting classes, using ICT by teachers, preparing educational materials, types of means of communication with students during lessons and outside lecture hours, methods of control, and evaluation of students' work.

\section{Results}

The results of the interviews were written down and categorized into groups: methods of conducting classes, educational materials, means of communication with a student, evaluation and control of a student's work, comparison of contemporary and previously used teaching methods.

\subsection{Methods of conducting classes}

Apart from classical methods of teaching, such as lectures, and practical ways, such as solving tasks in exercises and laboratories, interviews with teachers revealed the presence of modern activating methods, such as gamification, and elements of project-based learning methods (PBL) supported by tools for remote teamwork.

Gamification. Educational games are quite often used by academic teachers on platforms and in courses of remote education and are very well received by students. They serve the student's interaction with the educational material, and this interaction takes the form of "on its own" and takes place in the virtual world (Yang, \& Chang, 2013; Simões et al., 2013; Zdonek, 2018). However, the games used in education can also take on another form, 
such as educational quiz shows. The most common way of quiz shows among the surveyed teachers was the one based on Kahoot. The application developed by Kahoot in 2013, where users can create their quizzes on a free platform for use by other users. Any user (in this case, a teacher) can create any quiz, in which, apart from the questions, they can give four answers (some are correct and some incorrect). The task of the students is to choose the right answers. They are awarded points for correct answers. At the end of the quiz, the ranking of the players is presented. Another form of quiz shows was based on group competition. During the classes, the students were divided into two subgroups who answered the teacher's questions and competed with each other for points entered on aboard. Points were awarded based on correct answers. Inter-group rivalry usually resulted in significant participation by students and gave them great motivation to answer questions. Although the students did not always provide accurate answers, the lack of consistency in the form of assessments meant that it was not perceived as a problem situation. Both Kahoot and inter-group rivalry introduced in the classes replaced traditional revision test checking knowledge and skills.

Project-Based Learning (PBL) and remote cooperation tools for students. PBL is a teaching method in which a student acquires knowledge and skills by working for a specified time on a comprehensive solution to a problem or issue (Han et al., 2014; Walker et al., 2015). This solution takes the form of a project, which students perform in groups. PBL assumes teaching by defining goals, providing content based on standards, and developing skills, including critical thinking, problem-solving, cooperation, and self-organization. Due to the high popularity of the PBL approach, it is more boldly used by teachers in works assigned to students in the form of projects that are part of the educational process. Excellent facilitation in this type of work is that it can be done remotely. Such solutions as Dropbox or Google Drive offer a lot of possibilities in this area, which enable file sharing and simultaneous work of several people on the same files.

Comparing the methods used today with those used in the past in education of the surveyed teachers, the interviews revealed that project-based methods were used in their educational process. Nevertheless, there were no technological possibilities to support teamwork with remote education tools. On the other hand, educational games were not present in the education of the surveyed academic teachers. They appeared only with the dissemination of devices such as Kahoot and the distribution of research on gamification.

\subsection{Didactic materials}

Interviews with the surveyed teachers showed that although written scripts and academic textbooks are still present, courses on remote education platforms are top-rated. They enable the replacement of traditional texts and instructional manuals with electronic materials prepared by the teacher. Their preparation is based on teaching methods in forms made available by the platform (e.g., books, lessons), thanks to which instructional materials are created, as well as activating methods, which allow for the creation of training materials. 
The instructional materials can be static, similar to classic printed materials, or dynamic, in the form of educational films. In contrast to traditional academic textbooks, the teacher can update and change the materials posted on the platform on an ongoing basis. An additional advantage of these courses is that they enable students not only to browse the instructional materials but also to interact with the training materials. These can take the form of a traditional set of tasks or educational games, as well as tests. Such arrangements make it possible to introduce an element of student self-evacuation into the educational process, in a way that eliminates the stress associated with tests. Games and quizzes return results automatically, which significantly increases students' motivation to improve their results. It has been noted that students willingly take advantage of the opportunity to improve their score and take a test several times or play the same game multiple times. In this way, they increase the effectiveness of the retention of knowledge passed on to them. Preparation of feeding and activating materials for students requires considerable creative skills and a lot of work from the teacher. The effort put into the prepared courses results in substantial involvement on the part of the students. They willingly use educational games as revision materials before the final semester tests. On the other hand, instructional materials are conducive to the high quality of their independent work on projects as part of the proposed PBL approach.

Interviews with academic teachers have indicated a significant change in the use of teaching methods and tools in the past and now. Currently, young people prefer materials published online or on e-learning platforms to those available in scripts or books. In the past, teachers had chalk, a blackboard, and, possibly, the necessary props for lectures. Still, now it is difficult to find a teacher who would not be supported by multimedia presentations or various types of Internet applications.

\subsection{Ways of communicating with a student}

A dozen or so years ago, the interaction between a student and a teacher was based on personal contact during designated consultations in a specific time and place. The dates of discussions were previously given at lectures or exercises and hung in areas designated for this purpose (Dean's offices, showcases next to staff rooms). At many Polish universities, this rule still applies, but other forms of cooperation and communication between the teacher and the student have also appeared. At the moment, every academic teacher is obliged to have an e-mail address, thanks to which they contact students, send the necessary materials for classes, and solve problems that arise on an ongoing basis. These are particularly helpful and fast means of communication when a teacher has, under their care, a student with the so-called Individual Course of Studies, who changes the field of studies or an international student taking part in an international program (e.g., Erasmus). Some teachers prefer to be contacted by phone, particularly if they want to contact a group quickly or provide relevant information. They usually exchange telephone numbers with the head of the group or a student chosen by the majority. Apart from e-mail and telephone contact, many academic teachers have their 
websites, where they place materials needed for classes, additional information on necessary literature, or their academic achievements.

Many academic teachers use various e-learning platforms in their classes, where they develop courses for their classes. Additional tools helpful in the interaction between academic teachers and students are Internet forums and news on remote education platforms. Moreover, teachers communicate with students more and more often through social media or communicators. This form of communication is very suitable, particularly to students of Generation Z.

\subsection{Evaluation and control of a student's work}

All methods of verifying the achievement of educational results by students, assumed within the framework of the realization of particular subjects, are specified in syllabuses. The syllabus specifies the methods of verifying the achievement of the expected educational results, taking into account the characteristics of the material. Different means of verifying educational results are applied, adjusted to the profile of a graduate of a field of study and specialization, as well as to the teaching objectives and educational achievements in the scope of knowledge, skills, and competences. The student's assessment is based on periodical control work in the form of tests, papers, projects, reports, and descriptions of case studies, individual or group work, and diploma theses. Examinations may be conducted in writing or orally. In each case, the examination tasks must be formulated from the point of view of the learning outcomes recorded in the syllabuses of subjects. The methods of assessment of a student's work have been the same for many years, but the widespread use of IT solutions has resulted in a change in the form of this assessment. For example, more and more often, students' credit work is carried out in the way of a multimedia presentation or is supported by other computer software. In addition to this, written final exams or tests can be developed in electronic form on a remote education platform. Tests prepared in this way may contain time limitations, have a specified deadline, or provide current information about the correctness of the task.

Using ICT tools to evaluate and control a student's work certainly has many advantages. However, it is also essential to mention some difficulties for the teacher to check the work for plagiarism or cheating during exams or credits. Students willingly use various types of electronic gadgets with Internet access (smartwatch, microphones, wristbands). Moreover, students can easily duplicate their credit papers among themselves, as well as obtain materials and documents on various Internet portals for consideration. Of course, various anti-plagiarism programs can be used to check the work, but this requires additional effort and vigilance on the part of the teacher. In their interviews, academic teachers emphasized that even though modern IT tools are beneficial in the evaluation and control of a student's work, they often require more vigilance when verifying the independence of the work. 


\section{Discussion and conclusion}

The results of the research confirmed that the students of Generations $\mathrm{Y}$ and $\mathrm{Z}$ forced the transformation of teaching methods on contemporary academic teachers. Therefore, like K. Beckman and others (Beckman et al., 2014), it must be acknowledged that this phenomenon is related to other learning methods preferred by this generation. However, the transformation of processes does not mean a complete abandonment of existing teaching methods, but an addition to the new means and tools.

Although the results of the research seem to fit into the pedagogics area, they are strictly applicable to human resources management. Changing environmental conditions forces that every contemporary company trains its employees. Therefore, organizations should be aware of the influence of generational changes on teaching methods in the field of teaching information and communication technologies. It will increase teachers' competence and teaching quality.

Many of the emerging methods are related to new communication and information processing technologies. An example is the positive impact of social media on the development of forms of education, such as courses on remote learning platforms. These courses enable teachers to create teaching materials that are independent of the publishing process and which can be not only static but also dynamic in the form of viral educational films. Of course, the use of such educational forms requires teachers to continually improve their skills, even in areas that are not related to the informative content they teach. Another example of the positive impact of technology on teaching methods is the improvement of the Project-Based Learning method with the use of remote teamwork tools. The interviews also confirmed, similarly to the research conducted by D.M. Hanus and J. Fox (Hanus, 2015), that the presence of games in the life of contemporary youth has resulted in a growing trend of using the mechanism of games in the educational process, i.e., the so-called gamification, among academic teachers. Of course, apart from the bright sides of modern technologies, there are also darker sides. An example is the possibility for students to duplicate their theses, use paid websites offering developed topics or cheating during tests using mobile technologies (sending text messages, using the Internet with electronic watches - smartwatches).

This article presents the results of qualitative research, which allowed us to initially determine the characteristics of the phenomenon of generational changes and their impact on the teaching methods used. In the further research process, the authors intend to explore the topic from the point of view of quantitative research by conducting surveys among both academic teachers and students. 


\section{References}

1. Beckman, K., Bennett, S., \& Lockyer, L. (2018). Understanding students' use and value of technology for learning. Learning, Media and Technology, 39(3), pp. 346-367.

2. Dolot, A. (2018). The characteristics of Generation Z. E-mentor, 2(74). Warszawa: Warsaw School of Economics, pp. 44-50.

3. Gadommska-Lila, K. (2015). Pokolenie Y wyzwaniem dla zarządzania zasobami ludzkimi. Zarzadzanie zasobami ludzkimi, 1. Warsaw: IPiSS, pp. 25-39.

4. Generacja $Z$ - pokolenie które zmieni nasz świat. Retrieved from http://hatalska.com/ 2015/01/22/generacja-z-pokolenie-ktore-zmieni-nasz-swiat, 18.02.2019.

5. Girard, C., Ecalle, J., Magnan, A. (2013). Serious games as new educational tools: how effective are they? A meta-analysis of recent studies. Journal of Computer Assisted Learning, 29, pp. 207-219.

6. Grenčíková, A., Vojtovič, S. (2017). Relationship of generations X, Y, Z with new communication technology. Problems and Perspectives in Management, 15, 2, p. 558-564.

7. Han, S., Capraro, R., Capraro, M.M. (2014). How science, technology, engineering, and mathematics (STEM) Project-Based Learning (PBL) affects high, middle, and low achievers differently: the impact of student factors on achievement. International Journal of Science and Mathematics Education, National Science Council, Taiwan.

8. Hanus, M.D., Fox, J. (2015). Assessing the effects of gamification in the classroom: A longitudinal study on intrinsic motivation, social comparison, satisfaction, effort, and academic performance. Computers \& Education, 80, pp. 152-161.

9. Hysa, B. (2016). Różnorodność pokoleniowa. Zeszyty Naukowe Politechniki Śląsiej. Organizacja i Zarządzanie, 97, Gliwice, pp. 385-398.

10. Kisielnicki, J., Nowacka, B. (2013). Modele nauczania e-learningowego i ich ocena Analiza porównawcza na przykładzie PJWSTK i Uczelni Łazarskiego. In: L. Banachowski (Ed.), Postęy e-edukacji. Warszawa: Wydawnictwo PJWSTK, pp. 41-52.

11. Kopertyńska, M.W., Kmiotek, K. (2014). Budowanie zaangażowania pracowników pokolenia Y. In: G. Bełz, A. Barabasz (ed.), Prace Naukowe UE we Wrocławiu, 358, Management Forum, 4. Wydawnictwo Naukowe UE we Wrocławiu, pp. 39-48.

12. Luscombe, J., Lewis, I., Biggs, H.C. (2013). Essential elements for recruitment and retention: Generation Y. Education + Training, 55, 3, pp. 272-290. Emerald Group Publishing Limited.

13. Lyons, S.T., Schweitzer, L., Ng, E.S.W. (2015). How have careers changed? An investigation of changing career patterns across four generations. Journal of Managerial Psychology, 30, 1, pp. 8-21.

14. Martí-Parreño, J. et al. (2016). The use of gamification in education: a bibliometric and text mining analysis. Journal of Computer Assisted Learning, 32, 6, pp. 663-676. 
15. Report JWT: Gen Z: Digital in Their DNA. Retrieved from: https://www.slideshare.net/ jwtintelligence/f-external-genz041812-12653599/14-SPENDERS_FIRST_SAVERS_ SECOND_FIGURE, 18.02.2019.

16. Simões, J., Redondo, R.D., Vilas, A.F. (2013). A social gamification framework for a K-6 learning platform. Computers in Human Behavior, 29, pp. 345-353.

17. Stosik, A., Leśniewska, A. (2015). Innowacyjne rozwiązania w zarządzaniu zasobami ludzkimi - perspektywa adaptacji i różnic pokoleniowych. Studia i prace Wydziału Nauk Ekonomicznych i Zarzadzania, 39, 3, Szczecin: WNUS, pp. 183-196.

18. The Deloitte Millennial Survey (2017). Apprehensive millennials: seeking stability and opportunities in an uncertain world. Retrieved from: https://www2.deloitte.com/ru/en/ pages/about-deloitte/articles/2017/millennialsurvey.html, 18.02.2019.

19. Vojtovič, S. (2017). Relationship of generations X, Y, Z with new communication technology. Problems and Perspectives in Management, 15, 2, pp. 558-564.

20. Walker, A. et al. (2015). Essential readings in problem-based learning. West Lafayette: Purdue University Press.

21. Yang, Y.C., Chang, C. (2013). Empowering students through digital game authorship: Enhancing concentration, critical thinking, and academic achievement. Computers \& Education, 68, pp. 334-344.

22. Zdonek, I. (2018).Gamification in higher education - Polish experience. INTED 2018, Valencia, Spain. L. Gomez Chova, A. Lopez Martinez, I. Candel Torres (ed.). IATED Academy, pp. 5544-5548. 